\title{
Production of Oxalic Acid by Aspergillus niger using Chlorella Vulgaris Grown with an Industrial Effluent as a Potential Feedstock
}

\author{
Chioma DM* and Agwa OK \\ Department of Microbiology, University of Port Harcourt, Nigeria
}

Submission: May 03, 2018; Published: July 02, 2018

*Corresponding author: Chioma DM, Department of Microbiology, Faculty of Science, University of Port Harcourt, PMB 5323 Port Harcourt, Rivers state, Nigeria, Tel: +234-8035757992; Email: obioma.agwa@uniport.edu.ng / dennis_chioma@uniport.edu.ng

\begin{abstract}
The potential of Chlorella vulgaris as a feedstock for production of oxalic acid through fermentation process was investigated. Chlorella vulgaris was obtained by blooming in 60:40 industrial effluents and freshwater under natural illumination by submerged fermentation at a retention period of 14days. The Aspergillus niger spores were standardized and inoculated into the algal formulated medium for oxalic acid production and the oxalic acid produced was assayed using gas chromatography-mass spectrophotometry. Result showed that the total carbon, nitrogen and phosphates content of the algal slurry were $9.85 \mathrm{ppm}, 18.73 \mathrm{ppm}$ and $1.75 \mathrm{ppm}$ respectively. The optimum temperature for the production of the acid was $30{ }^{\circ} \mathrm{C}$ and $\mathrm{pH} 6$ respectively. The GC-MS result revealed that the algal formulations produced $8.48 \mathrm{mg} / \mathrm{g}$ of oxalic acid. This work indicates that algal formulations would serve as a cheaper substrate for oxalic acid production and recommended for industrial application.
\end{abstract}

Keywords: Aspergillus niger; Chlorella vulgaris; Effluent; Fermentation; Oxalic acid

\section{Introduction}

Oxalic acid is a soluble, dicarboxylic acid with the formula, H2C2O4 which can also be called ethanedioic acid. Oxalic acid has wide applications in food as a preservative in postharvest ripening of banana and can serve as anti-browning agent [1], agricultural and textile industries. Its dissociation in bioleaching of iron and different metals has made it important in hydrometallurgy [2]; a major cleansing agent [3] and has been used to remove rust from pipes [4]. Conventionally, most oxalic acids are synthesized by chemical processes which include oxidation of olefins and glycols, oxidation of carbohydrates with trioxonitrate (v) acid, decomposition of formates followed by tetraoxosulphate (vi) acid treatment [5]. Unfortunately, these chemical processes have been reported to be eco-harmful thus, the need for a more sustainable and environment-friendly approach.

Biosynthetically, oxalic acid can be produced by certain microorganisms, plants and animals [6]. Some microorganisms that have produce oxalic acid include: Aspergillus ficuum [2]; Glyophyllum trabeum [2]; Paxillus involutus [7]; Penicillium oxalicum [8] and Aspergillus niger [4]. Among these microorganisms, A. niger has been reported to give the highest amount of oxalic acid, hence its preference over other isolates. The organism is generally accepted because of ease of handling, rapid growth and ability to ferment versatile cheap raw materials $[9,10]$.

In a bid to produce oxalic acid from cheap substrates, a variety of substrates such as: milk whey [11]; cashew apple juice [5,9]; molasses [12]; sweet potato hydrolysate [13] and corncobs have all been investigated. However, no research on oxalic acid production has been conducted with algal biomass slurry as source of carbon. Chlorella sp. is a microscopic cell $(<10 \mu \mathrm{m}$ diameter) with physiological characteristics similar to plants [14], an eukaryotic green microalga which replicates, grows optimally in aerated and well humified environment [15]. Chlorella vulgaris can be cultivated by photoautotrophic, heterotrophic and mixotrophic methods and can be used as animal feeds [16]; in the pharmaceutical, agricultural and nutraceutical industries as food for man. Hence, it can serve as a good nutrient source for fermentation processes. This study was conducted to assess the potential of Chlorella vulgaris biomass for oxalic acid production using A. niger in submerged fermentation technique. 


\section{Materials and Methods}

\section{Sample collection}

The effluent and freshwater samples for the algal cultivation were obtained from a food industry within Choba, Port Harcourt, Rivers State Nigeria. The samples were filtered using Whatman filter paper, sterilized and stored in a refrigerator at $4{ }^{\circ} \mathrm{C}$ until required.

\section{Microlagae and culture medium}

The microalgae used in this study were obtained from the department of microbiology, University of Port Harcourt, Nigeria. A pure culture of the organism was obtained by repeated sub-culturing of the isolate on nutrient agar using spread plate technique, a mixture of chloramphenicol $(62.5 \mu \mathrm{g}$. $\mathrm{ml}$ ) and nystatin $(100 \mu \mathrm{g} / \mathrm{ml})$ was added to the culture medium to ensure free fungal and bacterial cultures. The algal strain was selected after preliminary screening using biochemical and morphological characteristics and was finally maintained on agar slants until when required [17].

\section{Cultivation}

Five milliliters of the bloomed culture was aseptically inoculated into flasks containing effluent-and freshwater medium. About $1 \mathrm{ml}$ of the bloomed culture was inoculated into a defined synthetic medium $(0.132 \mathrm{~g} / \mathrm{L}$ Potassium nitrate, $0.066 \mathrm{~g} / \mathrm{L}$ sodium silicate, $0.066 \mathrm{~g} / \mathrm{L}$ monosodium phosphate and $0.066 \mathrm{~g} / \mathrm{L}$ EDTA. The $\mathrm{pH}$ of the medium was adjusted to 6.5 with $4 \mathrm{M} \mathrm{NaOH}$ prior to autoclaving at $121^{\circ} \mathrm{C}$ for 15 minutes [17]. The setups were maintained at $28 \pm 2{ }^{\circ} \mathrm{C}$ under natural illumination and aerated intermittently by shaking at interval for 14 days. Samples were periodically removed every $48 \mathrm{~h}$ to monitor changes in algal concentration, optical density and biomass as dry weight was determined.

The American and Public Health method were used to determine the chemical composition of the effluent. All experiments were designed in triplicates. The Statistical Software of Statistical Package for Social Sciences (SPSS) was used for the statistical analysis. The Posthoc test was used to test for the significant difference at $p$-value $<0.05$ within the group measured at $95 \%$ confidence level.

\section{Inoculum preparation for oxalic acid production}

The oxalic acid producing strain of Aspergillus niger used in the study was locally sourced from the department of Microbiology, University of Port Harcourt, Choba, Nigeria. Spores of A. Niger were grown on Potato dextrose agar (PDA) for $5-7$ days at $30{ }^{\circ} \mathrm{C}$. Afterwards, the spores were aseptically transferred into $100 \mathrm{ml}$ sterile distilled water flask [4].

\section{Oxalic acid determination}

A slight modification of Emeko et al. [4] was adopted for the medium formulation and fermentation study. The medium consisted of $50 \mathrm{~g}$ of algal slurry, $1.6 \mathrm{~g} / \mathrm{L}$ of yeast extract, $0.025 \mathrm{~g} / \mathrm{L}$ of yeast extract, $0.025 \mathrm{~g} / \mathrm{L}$ of $\mathrm{MgSO} 4.7 \mathrm{H} 20$ and $0.5 \mathrm{~g} / \mathrm{L}$
KH2PO4. The medium was adjusted to $\mathrm{pH} 6.0$ using $4 \mathrm{M} \mathrm{NaOH}$ solutions prior to sterilization. In this work, the oxalic acid produced was measured using the gas chromatography-mass spectrophotometry and the catalytic kinetic spectrophotometry documented by Jiang et al. [18].

\section{Result}

The nutrient index observed in this investigation have been shown to be necessary for the growth of micro algae. The dissolved oxygen for industrial effluent was $2.870 .03 \mathrm{ppm}$ while that of the freshwater was shown to be $5.170 .04 \mathrm{ppm}$ and there exists a significant difference between samples. The $\mathrm{pH}$ of the industrial effluent and freshwater samples were observed as follows $7.75 \pm 0.01$ and $6.89 \pm 0.03$ respectively and the result indicates existence of a significant difference between both samples and regulatory standard (FEPA) of pH 6.0 as shown in Table 1 . The salinity for effluent and freshwater samples were reported to be $35.65 \pm 0.78 \mathrm{ppm}$ and $252.5 \pm 3.4 \mathrm{ppm}$ and this varied from FEPA standard of $90 \mathrm{ppm}$. The phosphate contents of the effluent and freshwater samples were 18.6c and 2.15, the values of the samples varied from the FEPA standard of 7.0. The optical density of Chlorella sp. revealed an increase from 0.145 abs at $620 \mathrm{~nm}$ to $0.789 \mathrm{abs}$ at $620 \mathrm{~nm}$ after 14 days of culture while the cell dry weight also increased from $0.112 \mathrm{mg} / 10 \mathrm{ml}$ to $0.267 \mathrm{mg} / 10 \mathrm{ml}$ as shown in Figure $1 \&$ Figure 2 respectively. Table 2 below shows the physico-chemical characteristics of the algal biomass slurry used in this work. The result shows a high concentration of calcium $(19.1 \mathrm{mg} / \mathrm{g})$ and total nitrogen content (18.73mg/g).

Table 1: Physico chemical characteristics of effluent and fresh water.

\begin{tabular}{|c|c|c|c|}
\hline Parameters & Effluent & Fresh Water & FEPA \\
\hline pH & $7.75 \pm 0.01^{\mathrm{c}}$ & $6.89 \pm 0.03^{\mathrm{b}}$ & $6.0^{\mathrm{a}}$ \\
\hline $\begin{array}{c}\text { Salinity (mg/L) } \\
\text { Electrical conductivity } \\
(\mu \mathrm{S} / \mathrm{cm})\end{array}$ & $35.65 \pm 0.78^{\mathrm{a}}$ & $252.5 \pm 3.54^{\mathrm{c}}$ & $90^{\mathrm{b}}$ \\
\hline $\begin{array}{c}\text { Dissolved oxygen } \\
(\mathrm{mg} / \mathrm{L})\end{array}$ & $2.15 \pm 0.05^{\mathrm{a}}$ & $871.7 \pm 2.7^{\mathrm{c}}$ & $120^{\mathrm{b}}$ \\
\hline Total hardness (mg/L) & $6.1 \pm 0.02^{\mathrm{b}}$ & $5.17 \pm 0.04^{\mathrm{c}}$ & $4.0^{\mathrm{b}}$ \\
\hline $\begin{array}{c}\text { Total Dissolved solids } \\
\text { (mg/L) }\end{array}$ & $80.0 \pm 1.0^{\mathrm{b}}$ & $2.05 \pm 0.05^{\mathrm{a}}$ & $500^{\mathrm{c}}$ \\
\hline $\begin{array}{c}\text { Total organic carbon } \\
\text { (mg/L) }\end{array}$ & $31.74 \pm 0.46^{\mathrm{c}}$ & $4.54 \pm 0.46^{\mathrm{b}}$ & $0.05^{\mathrm{a}}$ \\
\hline $\begin{array}{c}\text { Chemical oxygen } \\
\text { demand (mg/L) }\end{array}$ & $72 \pm 1.0^{\mathrm{b}}$ & $6.45 \pm 0.06^{\mathrm{a}}$ & $430^{\mathrm{c}}$ \\
\hline $\begin{array}{c}\text { Biochemical Oxygen } \\
\text { demand (mg/L) }\end{array}$ & $6.54 \pm 0.06^{\mathrm{c}}$ & $0.16 \pm 0.02^{\mathrm{a}}$ & $6.0^{\mathrm{b}}$ \\
\hline Total nitrogen (mg/L) & $16.51 \pm 0.49^{\mathrm{c}}$ & $2.65 \pm 0.065^{\mathrm{a}}$ & $5.0^{\mathrm{b}}$ \\
\hline Phosphate (mg/L) & $18.60 \pm 0.46 \mathrm{c}$ & $2.15 \pm 0.01^{\mathrm{a}}$ & $7.0^{\mathrm{b}}$ \\
\hline Ammonia (mg/L) & $4.89 \pm 0.11^{\mathrm{b}}$ & $0.67 \pm 0.08^{\mathrm{a}}$ & $150.0^{\mathrm{c}}$ \\
\hline Sulphate (mg/L) & $0.27 \pm 0.06^{\mathrm{a}}$ & $1.06 \pm 0.02^{\mathrm{b}}$ & $500^{\mathrm{c}}$ \\
\hline Nitrate (mg/L) & $0.55 \pm 0.05^{\mathrm{b}}$ & $0.09 \pm 0.01^{\mathrm{a}}$ & $10^{\mathrm{c}}$ \\
\hline
\end{tabular}

Means \pm Standard Error; superscripts with the same alphabet in a given row are statistically insignificant at $p<0.05$. 
Table 2: Chemical composition of algal slurry.

\begin{tabular}{|c|c|}
\hline Parameter & Value \\
\hline Alcohol content & $0.48 \%$ \\
\hline Magnesium (ppm) & 1.83 \\
\hline Manganese (ppm) & 0.48 \\
\hline Zinc (ppm) & 0.31 \\
\hline Calcium (ppm) & 19.1 \\
\hline Total nitrogen (ppm) & 18.73 \\
\hline Phosphorus (ppm) & 1.75 \\
\hline Total carbon (ppm) & 9.85 \\
\hline Iron (ppm) & 1.01 \\
\hline
\end{tabular}

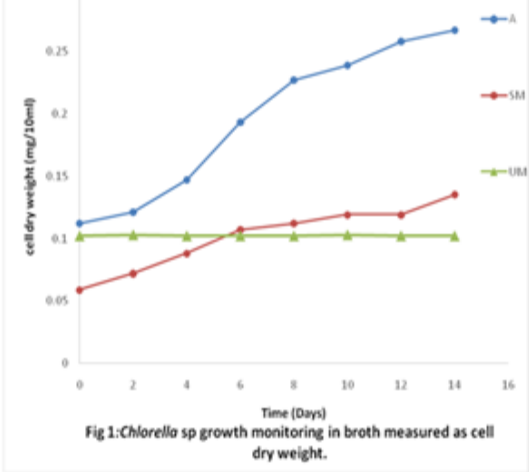

Figure 1: Keys.

A: Algal Biomass in Effluent-Freshwater Medium SM: Synthetic Medium

UM: Uninoculated Medium.

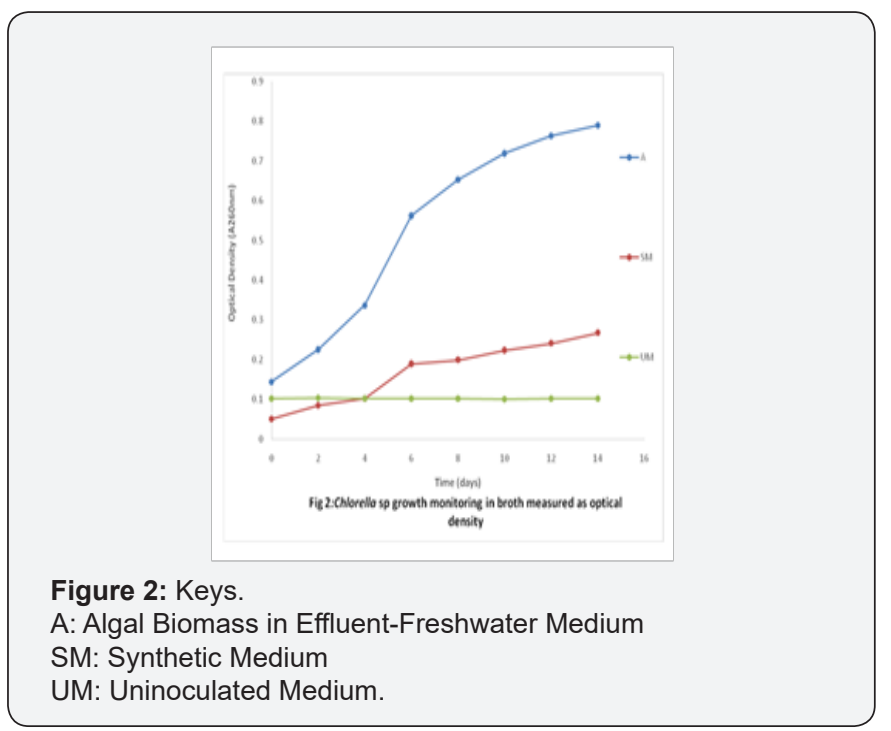

Furthermore, the study revealed that the best conditions for oxalic acid fermentation were $\mathrm{pH} 6$ and $30{ }^{\circ} \mathrm{C}$ as both conditions gave the highest oxalate concentrations of $10.55 \mathrm{ppm}$ and 8.98ppm respectively after 10 days of fermentation as seen in Figure 3 and Figure 4 . The final oxalic acid produced at $30{ }^{\circ} \mathrm{C}$ and $\mathrm{pH} 6.0$ was reported to be $8.48 \mathrm{mg} / \mathrm{g}$ with retention time of 12.621. Other organic acids like pyruvic, citric, malonic acids were also synthesized along the oxalic acid.

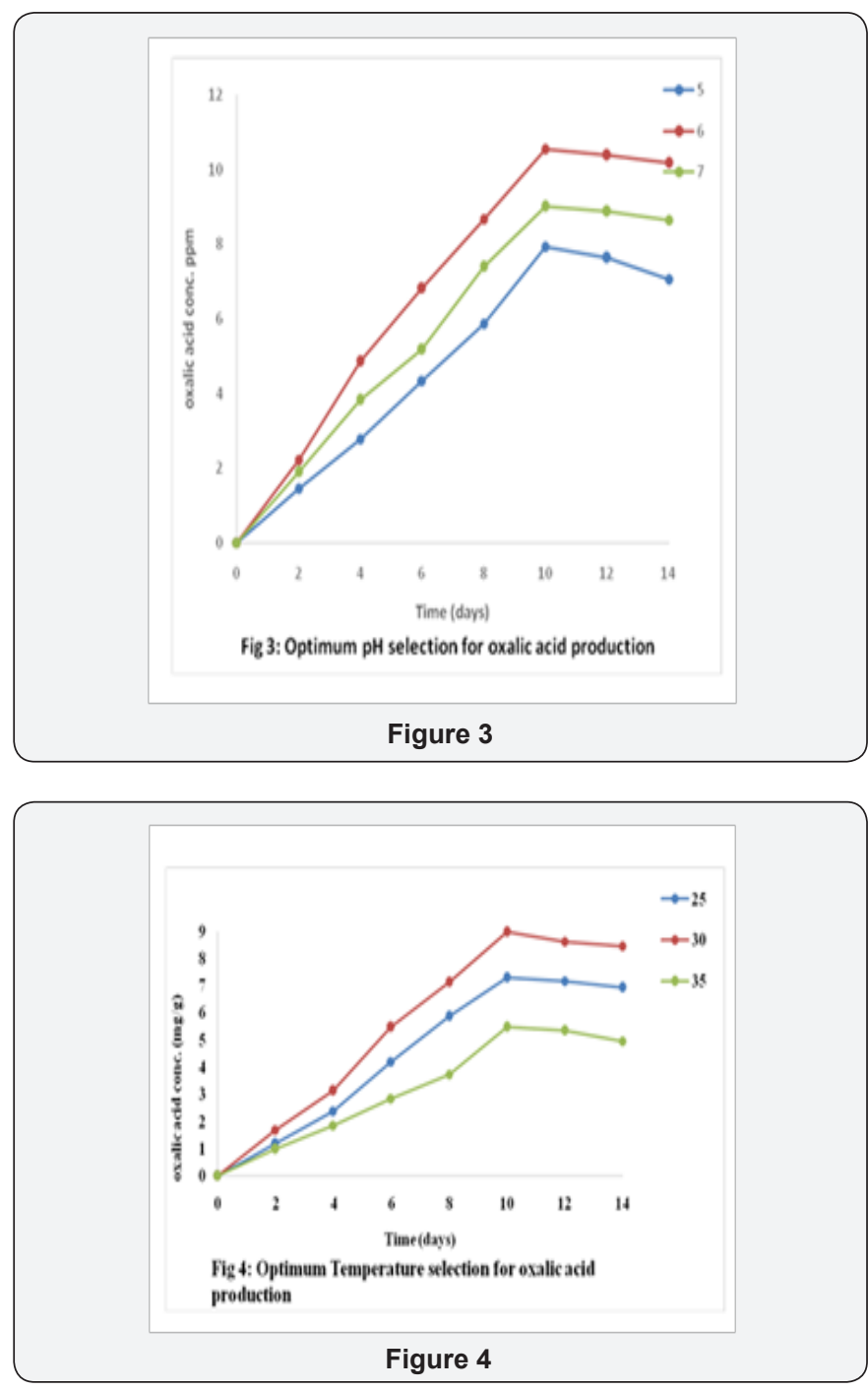

\section{Discussion}

Effluent treatment and disposal especially from industrial activities have become a huge challenge to manufacturing processes all around the world. Stiffer limits have been proposed to both safeguard the discharge of harmful materials into ecosystems and possibly reuse them for industrial benefits. The growth of Chlorella sp. using industrial effluent medium revealed inherent micronutrients found within the effluent proved its suitability as growth medium. The report concurs with Grima et al. [19] who showed that microalgae can be grown in sea water supplemented with phosphates and nitrates. Amanullah (2007) \& Iyoyo et al. (2010) opines that most microalgae can be grown with wastes rich in phosphorus and nitrogen. These nutrients innate within the waste were necessary for the growth of the organism [15]. Poultry waste extracts and industrial dairy waste have also been shown to support the cultivation of microalgae $[17,20]$. Enitan et al. [21] observed that effluents could be applied to the production of a wide variety of bioactive materials as a cheap source of nutrients. These findings all agree with the need and viability of microalgae cultivation with cheap and inexpensive materials (Figure 5). 

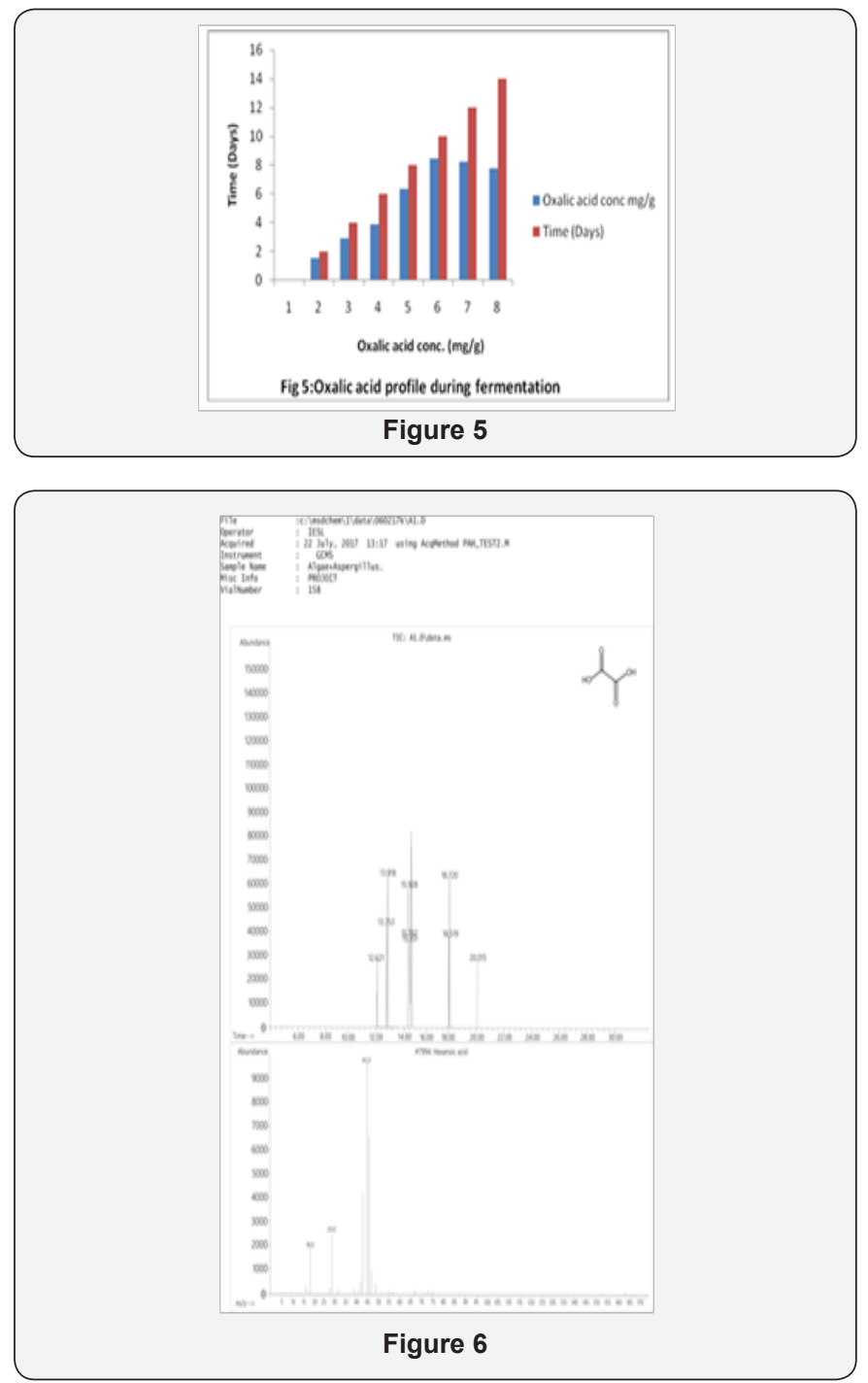

The reportedly low $\mathrm{pH}$ levels in the effluent in this study could suggest a lower carbon concentration, in the form of carbonates and bicarbonates. Conversely, Roselin (2015) reported that $\mathrm{pH}$ of sewage water could range from 6.3-7.3. The increased nitrate level in the effluent suggests the presence of high nitrogen-containing compounds in the wastewater. The nitrate levels reported in this work also disagrees with Ahmad et al. [22] who reported a higher nitrate content of $1.19 \mathrm{ppm}$. However, the nitrate content reported in this work is similar to that of Nwosu et al. [23] that reported a nitrate concentration of $0.683 \mathrm{ppm}$ from a food factory during the rainy season and higher than the nitrate content of 0.106 (Figure 6).

It has been well reported that fermentation medium for oxalic acid production must contain carbon and nitrogen sources [5]. Algal starch has been reported to be readily used by yeast via fermentation for the production of ethanol and organic acids $[24,25]$. The biochemical composition of algae is a function of the species, temperature, light and growth stage. A variation in the biochemical composition due to growth stage is frequently affected by the stage of the culture and nutrient exhaustion [26]. Basically, algal cultures become depleted in nutrients as they enter stationary stages of growth, while protein content declines, total carbon content increases $[27,28]$.

The study reported a high concentration of total nitrogen content $(18.73 \mathrm{ppm})$ in the algal slurry which is in contrast with the report of Dineshkumar et al. [29] on algal biomass slurry. The difference could be attributed to the difference in nature of biomass used in the investigation. Dineshkumar et al. [29] also reported a higher carbon concentration of $20.42 \pm 0.33 \mathrm{mg} / \mathrm{g}$ on dry biomass. This disparity could be as a result of the difference in the algal growth medium. Furthermore, Giselle et al. [30] reports a carbohydrate content of $7.09 \pm 0.84$ and protein content of $6.07 \pm 1.14$ in Chlorella sp that has attained stationary growth phase. This study also differs with Lum et al. 2013 who reported $12-17 \%$ carbohydrates dry weights, $14-22 \%$ lipids and $51-58 \%$ proteins in Chlorella sp. The disparity could be attributed to the fact that the microalgae were possibly in the exponential phase of growth. Also, factors such as environmental factors, nutritional factors and protein production can affect the carbohydrate content and ultimately total carbon content in microalgal species Abdelkhalek et al. [31].

The optimum $\mathrm{pH}$ and temperature reported in this work agree with Rujiter et al. [32]; Mandal \& Banerjee [4,33]. The yields reported in this work do not corroborate with Betiku et al. [5] who reported an oxalic acid yield of $38 \mathrm{mg} / \mathrm{g}$ from molasses and sweet potato starch hydolyzate with oxalic acid yield of $1,038 \mathrm{mg} / \mathrm{g}$ respectively. This disparity could be attributed to the choice and availability of the feedstock for metabolism by the fungus. Furthermore, the relative reduced yield in this work could also be linked to the non addition of methanol to the fermentation medium. Betiku et al. [5] reported an increased yield of oxalic acid after addition of $1 \%$ methanol to the fermentation medium. In addition [34], Cameselle et al. [11] reports that one of the challenges with oxalic acid formation via fermentation is the simultaneous production of gluconic at $\mathrm{pH} 7$, thus, recommends a strict control for the medium environment for optimum production (Figure 7).

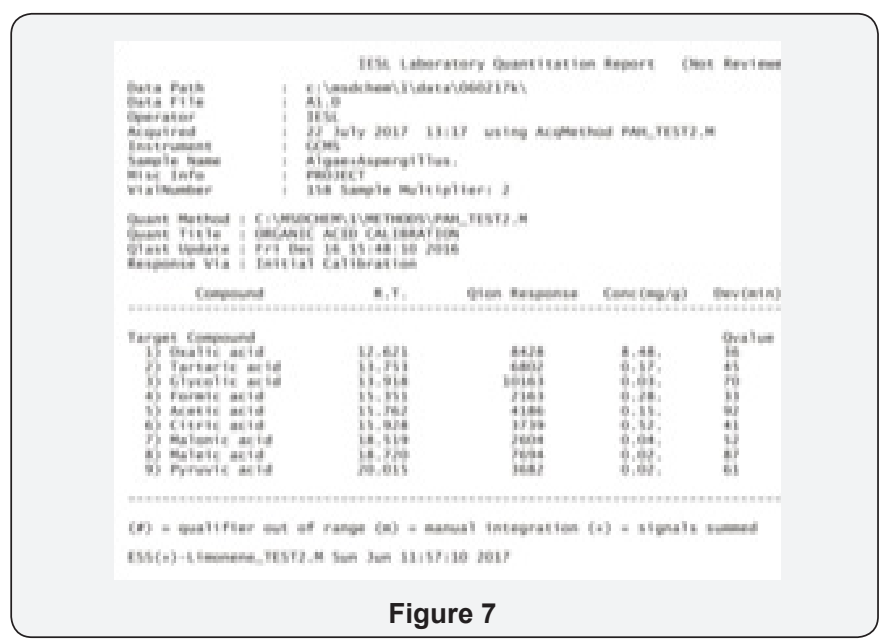




\section{Conclusion}

The prospect for submerged fermentation using Chlorella vulgaris biomass as feedstock for oxalic acid production was explored in this study [35-40]. The results showed that algal biomass had the necessary nutrients for oxalic acid production at $\mathrm{pH} 6$ and temperature of $30^{\circ} \mathrm{C}$ for 10 days [41-45]. The oxalic acid concentration reported at the end of the study period was $8.48 \mathrm{mg} / \mathrm{g}$. Algal biomass remain an untapped resource for the production of industry-important substances [46].

\section{References}

1. Son SM, Moon KD, Lee CY (2000) Kinetic study of oxalic acid inhibition on enzymatic browning. J Agric Food Chem 48(6): 2071-2074.

2. Strasser H, Burgstaller W, Schinner E (1994) High yield production of oxalic acid for metal leaching processes by Aspergillus niger. FEMS Microbiology letters 9(31): 365-370.

3. Musiał I, Rymowicz W, Lenart D, Witkowska D (2005) The use of postrefining fatty acids for oxalic acid production by Aspergillus niger at low pH. Biotechnologia Monografie 2(2): 37-45.

4. Emeko HA, Olugbogi AO, Betiku E (2015) Appraisal of artificial neural network and response surface methodology in modeling and process variable optimization of oxalic acid production. Bio Resources 10(2): 2067-2082.

5. Betiku E, Emeko HA, Solomon BO (2016) Fermentation parameter optimization of microbial oxalic acid producton from cashew apple juice. Heliyon 2(2): e00082.

6. Hodgkinson A (1977) Oxalic acid in biology and medicine, Academic Press, San Francisco, New York, USA.

7. Lapeyrie F, Chilvers GA, Bhen CA (1987) Oxalic acid synthesis by the mychorrizal fungus Paxillusinvolutus. New Phytologist 106(1): 139146.

8. Ikotum T (1984) Production of oxalic acid by Penicilliumoxalicum in culture and in infected yam tissue and interaction with macerating enzyme. Mycopathologia 88(1): 9-14.

9. Nadeem A, Syed Q Baig S, Irfan M, Nadeem M (2010) Enhanced production of citric acid by Aspergillus niger M-101 using lower Alcohols. Turkish Journal of Biochemistry 35(1): 7-13.

10. Pandey P, Putatunda S, Dewangan L, Pawar VS, Belorkar SA (2013) Studies on citric acid production by Aspergilllusniger in batch fermentation. Recent Research in Science and Technology 5(2): 66-67.

11. Cameselle C, Bohlmann JT, Nunez MJ, Lema JM (1998) Oxalic acid production by aspergillus niger. Part I: Influence of sucrose and milk whey as carbon source. Bioprocess Engineering 19(4): 247-252.

12. Podgórski W, Leśniak W (2003) Biochemical method of oxalic acid production from beet molasses. Chem Pap 57(6): 408-412.

13. Adesina OA, Oluwabunmi KE, Betiku E, Fatuntele LT, Ayodele OA, et al. (2014) Optimzation of process variables for the production of oxalic acid from sweet potato starch hydrozylate. Chemical and Process Engineering Research 18: 16-25.

14. Safi C, Liu D, Yap BJ, Martin GO, Vaca Garcia C, et al. (2014) A two stage ultrafiltration process for separating multiple components of Tetraselmis suecica after celldisruption. Journal of Applied Phycology 26(6): 2379-2387.

15. Agwa OK, Ibe SN, Abu GO (2012) Assessment of cow dung waste for the laboratory cultivation of Chlorella for lipid production. Astan Journal of Microbiol Biotech Env Sc 14(1): 1-6.
16. Chen YC (2003) Immobilized Isochrysisgalbana (Haptophyta) for longterm storage and applications for feed and water quality control in clam (Meretrixlusoria) cultures. Journal of Applied Phycology 15(5): 439-444.

17. Agwa OK, Abu GO (2014) Utilization of poultry waste for the cultivation of Chlorella sp. for biomass and lipid production. International Journal Current Microbiology and Applied Sciences 3(8): 1036-1047.

18. Jiang ZL, Mei Xiu Z, Lin Xiu L (1996) Catalytic spectrophotometric for the determination of oxalic acid. Anal Chim Acta 320(139-143).

19. Grima EM, Belarbi EH, Fernández FA, Medina AR, Chisti Y (2003) Recovery of microalgal biomass and metabolites: process options and economics. Biotechnology advances 20(7-8): 491-515.

20. Hena S, Fatimah S, Tabassum S (2015) Cultivation of algae consortium in a dairy farm wastewater for biodiesel production. Water and Resources Industry 10(1): 1-14.

21. Enitan AM, Adeyemo J, Kumari S, Swalaha FM, Bux F (2015) Characterization of brewery wastewater composition. International Journal of Environmental, Chemical, Ecological, Geological and Geophysical Engineering 9(9): 1073-1076.

22. Ahmad F, Khan AU, Yasar A (2013) The Potential of Chlorella vulgaris for wastewater treatment and biodiesel production. Pakistan Journal of Botany 45(S1): 461-465.

23. Nwosu UL, Ajiwe VIE, Okoye PC (2014) Physicochemical properties of effluents from three food processing industries in Anambara state, Nigeria. American Journal of Applied Chemistry 2(5): 91-95.

24. Nguyen MT, Choi SP, Lee J, Lee JH, Sim SJ (2009) Hydrothermal and pretreatment of Chlamydomonas reinhardtii biomass for ethanol production. J Microbiol Biotechnol 19(2): 161-166.

25. John RP, Anisha G, Nampoothia KM, Pandey A (2011) Micro and microalgal biomass: a renewable source for bioethanol. Bioresource Technology 102(1): 186-193.

26. Morris RJ, McCartney MJ, Robinson GA (1983) Studies of a spring phytoplankton bloom in an enclosed experimental ecosystem. I Biochemical changes in relation to the nutrient chemistry of water. J Exp Mar Biol Ecol 70(3): 249-262.

27. Ogbonna JC, Tanaka H (1996) Night biomass loss and changes in biochemical composition of cells during light/dark cyclic culture of Chlorella pyrenoidosa. J Ferm Bioeng 82: 558-564.

28. Catherine M, David MO, Daniel AK, Bruce CP, Vannessa AJ, et al. (2003) Biochemical composition of three algal species proposed as food for captive freshwater mussels. Journal of Applied Phycology 15(1): 1-11.

29. Dineshkumar R, Narendran R, Jayasingam P, Sampathkumar P (2017) Cultivation and chemical composition of Microalgae Chlorella vulgaris and its Antibacterial activity against human pathogens. Journal of Aquaculture and Marine Biology 5(3): 0019.

30. Giselle SC, Rodrigo RM, Elisabete B, Ricardo CM, Sergio OL (2012) Chemical composition of five marine microalgae that occur on the Brazilian coast. International Journal of Fisheries and Aquaculture 4(9): 191-201.

31. Abdelkhalek EI, Mohamed B, Mohamed MA, Lotfi A (2016) Growth performance and biochemical composition of nineteen microalgae collected from different Moroccan reservoirs. Mediterranean Marine Science 17(1): 323-332.

32. Rujiter GJG, Vondevourt PJ, Visser J (1999) Oxalic acid production by Aspergillusniger: an oxalate-non producing mutant produces citric acid at $\mathrm{pH} 5$ and in the presence of manganese. Microbiology 145: 25692576. 
33. Mandel SK, Banerjee PC (2006) Oxalic acid production by Aspergillus niger: influence of hydrogen ion concentration and nitrogen source. Research Journal of Microbiology 1(2): 190-197.

34. Ajay KG, Sushil S, Shubhi A, Rehka B (2011) Diversity pathogenicity and toxicology of A niger: an important spoilage fungi. Research Journal of Microbiology 6(3): 270-280.

35. Cleland WW, Johnson MV (1956) Studies on the formation of oxalic acid by Aspergillusniger. J Biol Chem 220(2): 595-606.

36. Eriksen NT (2008) The technology of microalgalculturing Biotechnology letters 30(9): 1525-1536.

37. Hiroshi H, Yuko S, Hiromi H, Yoshitaka A, Tokuma F, et al. (2009) Microbial production of glyceric acid, an organic acid that can be mass produced from glycerol. Applied and Environmental Microbiology 75(24): 7760-7766

38. Juneja A, Ceballos RM, Murthy GS (2013) Effects of environmental factors and nutrient availability on the biochemical composition of algae for biofuels production: a review. Energies 6(9): 4607-4638.

39. Madigan MT, Martinko JM, Dunlap PV, Clark DP (2008) Brock biology of microorganism's (12 $\left.{ }^{\text {th }} \mathrm{edn}\right)$. International Microbiology 11: 65-73.
40. Mai HTN, Lee KM, Choi SS (2016) Enhanced oxalic acid production from corncob by a methanol-resistant strain of Aspergillus niger using semi solid-state fermentation. Process Biochem 51: 9-15.

41. Mata TM, Martins AA, Caetano NS (2010) Microalgae for biodiesel production and other applications: a review. Renewable and Sustainable Energy Review 14(1): 217-232.

42. Pienkos PT, Darzins AL (2009) The promise and challenges of microalgal derived biofuels. Biofuels Bioproducts and Biorefining 3(4): 431-440.

43. Shanta T, Rati ER (1990) Isolation and characterization of an aatoxininhibiting metabolite from Aspergillusniger. Curr Sci 59: 326-327.

44. Tanaka K, Nonaka F (1981) Synergistic action of oxalic acid and pectinolytic enzyme on the rot of onion bulb caused by Aspergillus niger. Ann Phytopathol Soc Japan 47: 166-174.

45. Webster J (1980) Introduction to fungi. Cambridge University Press, London, p. 669.

46. Yang Z, Guo R, Xu X, Fan X, Li X (2010) Enhanced hydrogen production from lipid-extracted microalgal biomass residues through pretreatment. International Journal of Hydrogen Energy 35: 9618 9623.

Your next submission with Juniper Publishers will reach you the below assets

- Quality Editorial service

- Swift Peer Review

- Reprints availability

- E-prints Service

- Manuscript Podcast for convenient understanding

- Global attainment for your research

- Manuscript accessibility in different formats

( Pdf, E-pub, Full Text, Audio)

- Unceasing customer service

Track the below URL for one-step submission https://juniperpublishers.com/online-submission.php 